\title{
Asupan Aman Konsumsi Logam Cu Pada Kerang Darah dari Tempat Pelelangan Ikan Tambak Lorok, Semarang
}

\author{
Nurvita Agristiyani, Jusup Suprijanto*, Raden Ario \\ Departemen Ilmu Kelautan Fakultas Perikanan dan Ilmu Kelautan., Universitas Diponegoro \\ Jl. Prof. H. Soedarto S.H, Tembalang, Semarang, Jawa Tengah, 50275 Indonesia \\ Email: jusup.suprijanto@yahoo.co.id
}

\begin{abstract}
Abstrak
Kerang Darah (Anadara granosa) merupakan salah satu komoditas laut yang dihasilkan di Perairan Semarang. Lokasi tersebut diperkirakan telah menerima zat pencemar yang berasal dari limbah kota. Penelitian ini bertujuan untuk mengetahui kandungan logam berat Tembaga atau Cu (Cuprum) dan batas maksimal aman konsumsi mingguan jaringan lunak A. granosa yang diperoleh di Perairan Laut Semarang yang didaratkan di Tambak Lorok Semarang. Penelitian ini dilakukan dengan pengambilan sampel pada bulan Maret, April, Juni dan Juli 2020. Konsentrasi logam berat $\mathrm{Cu}$ dianalisis menggunakan ICP (Inductively Coupled Plasma) dan penetapan batas maksimal aman konsumsi dihitung menggunakan rumus EDI (Estimated Daily Intake) serta penilaian tingkat risiko menggunakan rumus THQ (Target Hazard Quotient). Hasil kandungan logam berat $\mathrm{Cu}$ pada jaringan lunak A. granosa di bulan Maret, April, Juni dan Juli 2020 masing-masing sebesar 0,705 mg/kg; 1,628 mg/kg; 2,209 mg/kg dan 1,149 mg/kg yang menunjukan bahwa kandungan logam berat $\mathrm{Cu}$ tidak melebihi ambang batas berdasarkan SK Depkes RI No.03725/B/SK/1989. Estimasi asupan harian (EDI) terhadap logam Cu di bulan Maret, April, Juni dan Juli 2020 yaitu sebesar 1,65 $\mu \mathrm{g} / \mathrm{kg} / \mathrm{hari} ; 3,80 \mu \mathrm{g} / \mathrm{kg} / \mathrm{hari} ; 5,15 \mu \mathrm{g} / \mathrm{kg} / \mathrm{hari}$ dan 2,68 $\mu \mathrm{g} / \mathrm{kg} / \mathrm{hari}$ yang menunjukkan bahwa dosis paparan $\mathrm{Cu}$ tergolong aman bagi konsumen A. granosa. Sedangkan penilaian tingkat risiko (THQ) untuk logam $\mathrm{Cu}$ menunjukkan hasil lebih kecil satu dengan nilai rata-rata 0,03 sehingga dapat dikatakan konsentrasi logam $\mathrm{Cu}$ tersebut tidak berpotensi menimbulkan efek nonkarsinogenik pada manusia.
\end{abstract}

Kata kunci : Anadara granosa, Kesehatan Manusia, Semarang, Tembaga

Abstract

\section{Safe Intake of Metal Consumption of Cu in Blood Cockle From TPI Tambak Lorok}

Blood Cockle (A. granosa) is one of the marine commodities produced in Semarang waters. The location is thought to have received pollutants from municipal waste. This study aims to determine the content of heavy metal $\mathrm{Cu}$ in A. granosa cockle obtained in Semarang sea waters which landed at Tambak Lorok Semarang. This research was conducted with sampling in March, April, June and July 2020. The concentration of heavy metal copper $(\mathrm{Cu})$ was analyzed using ICP (Inductively Coupled Plasma) and the determination of the maximum safe consumption limit was calculated using the EDI (Estimated Daily Intake) formula and risk level assessment was calculated using the THQ (Target Hazard Quotient) formula. The results of heavy metal Cu content in A. granosa cockles in March, April, June and July 2020 were $0,705 \mathrm{mg} / \mathrm{kg} ; 1,628 \mathrm{mg} / \mathrm{kg} ; 2,209 \mathrm{mg} / \mathrm{kg}$ and $1,149 \mathrm{mg} / \mathrm{kg}$, which indicates that the heavy metal content of $\mathrm{Cu}$ does not exceed the threshold based on the Decree of the Ministry of Health RI No.03725/B/SK/1989. Estimated Daily Intake (EDI) of Cu in March, April, June and July 2020 is 1,65 $\mu \mathrm{g} / \mathrm{kg} /$ day; 3,80 $\mu \mathrm{g} / \mathrm{kg} /$ day; 5,15 $\mu \mathrm{g} / \mathrm{kg} /$ day and 2,68 $\mu \mathrm{g} / \mathrm{kg} /$ day which indicate that the dose of Cu exposure is safe for A. granosa consumers. Meanwhile, the results of the risk level assessment (THQ) for $\mathrm{Cu}$ metal is $>1$ which indicates that the concentration of $\mathrm{Cu}$ metal does not have the potential to cause non-carcinogenic effects in humans.

Keywords : Anadara granosa, Health Risk, Semarang, Copper 


\section{PENDAHULUAN}

Kota Semarang merupakan kota yang terletak di pesisir Pantai Utara Jawa. Kota Semarang disebut sebagai kota metropolitan dengan kepadatan penduduk yang tinggi mencapai 4.425 jiwa $/ \mathrm{km}^{2}$ (BPS Kota Semarang, 2020). Hal tersebut menjadikan kota ini berkembang sebagai daerah yang sangat berpotensi bagi kegiatan industri, perdagangan dan jasa seperti pembangunan bandara, pelabuhan dan PLTU. Pembangunan industri tersebut dapat mencemari perairan melalui aliran sungai menuju ke laut sehingga sangat berpotensi dalam mencemari biota yang hidup di perairan tersebut dan berdampak buruk bagi kesehatan manusia apabila mengkonsumsi biota yang tercemar. Salah satu logam berat yang dapat mencemari biota di lingkungan tersebut adalah Tembaga $(\mathrm{Cu})$. Widowati et al. (2008) menyatakan bahwa logam berat $\mathrm{Cu}$ berasal dari aktivitas manusia dan industri.

Logam berat $\mathrm{Cu}$ tergolong ke dalam logam berat esensial yang dibutuhkan suatu organisme dalam jumlah yang sedikit (Darmono, 1995). Namun logam berat $\mathrm{Cu}$ dalam konsentrasi yang melampaui batas dapat memberikan dampak negatif. Menurut Dewi et al. (2017), dampak negatif yang dapat terjadi akibat terlalu banyak mengkonsumsi makanan yang mengandung logam berat $\mathrm{Cu}$ melebihi batas toleransi dapat menimbulkan gejala keracunan seperti diare, sakit perut, mual, gagal ginjal, penyakit kuning apabila konsumsi terlalu tinggi maka dapat menyebabkan koma hingga kematian.

Biota yang digunakan dalam penelitian ini yaitu Kerang Anadara granosa. Kerang ini merupakan salah satu komoditas laut yang dihasilkan di Perairan Semarang (Barik et al., 2014). Penggunaan biota ini sebagai hewan uji akumulasi logam berat dikarenakan kerang mampu menyerap cemaran logam berat di perairan tercemar karena memiliki sifat filter feeder dan menetap (sessile) sehingga sangat berpotensi mengakumulasi logam berat di lingkungannya (Selpiani et al., 2015). Selain itu kerang ini memiliki tingkat toleransi yang tinggi terhadap perubahan lingkungan sehingga dapat bertahan hidup meskipun telah mengakumulasi logam berat (Firmansyaf et al., 2013). Logam berat yang terakumulasi dalam tubuh kerang dapat menimbulkan efek toksik apabila dikonsumsi dalam jumlah yang berlebihan. Tujuan dari penelitian ini yaitu untuk menganalisis kandungan logam berat tembaga $(\mathrm{Cu})$ pada jaringan lunak $A$. granosa yang didaratkan di TPI Tambak Lorok Semarang. Selain itu juga untuk menganalisis batas maksimal aman konsumsi harian dan menganalisis risiko kesehatan dalam mengkonsumsi jaringan lunak A. granosa yang mengandung tembaga $(\mathrm{Cu})$ yang didaratkan di TPI Tambak Lorok Semarang.

\section{MATERI DAN METODE}

Materi yang digunakan pada penelitian ini adalah sampel jaringan lunak $A$. Granosa dengan ukuran acak sebanyak $300 \mathrm{~g}$ yang diperoleh dari perairan laut Semarang. Perolehan sampel dilakukan dengan mengambil kerang dengan menggunakan alat tangkap garuk oleh nelayan yang melaut di perairan laut Semarang yang kemudian didaratkan di TPI Tambak Lorok Semarang.

Penelitian ini menggunakan metode analisis deskriptif untuk memperoleh fakta dengan tujuan memberikan deskripsi secara sistematis mengenai fakta, sifat dan hubungan antara fenomena yang diteliti (Cahyani et al., 2012). Pengambilan sampel dilakukan pada bulan Maret, April, Juni dan Juli 2020. Periode I, II, III, dan IV masing-masing berurutan dilakukan tanggal 1 Maret 2020, 24 April 2020, 29 Juni 2020 dan 24 Juli 2020.

Sampel jaringan lunak A. granosa dilakukan destruksi sesuai ketentuan SNI 012891-1992. Sampel tersebut selanjutnya dilakukan pengujian logam berat $\mathrm{Cu}$ di Balai Teknologi Pencegahan Pencemaran Industri Semarang. Pengujian logam berat $\mathrm{Cu}$ dilakukan sesuai ketentuan SNI 01-2896-1992 menggunakan alat ICP (Inductively Coupled Plasma). Analisis data dilakukan dengan menggunakan rumus EDI (Estimated Daily Intake) dan THQ (Target Hazard Quotient) (Soegianto et al., 2020).

\section{HASIL DAN PEMBAHASAN}

Kandungan logam berat $\mathrm{Cu}$ pada jaringan lunak A. granosa yang diperoleh di Perairan Tambak Lorok Semarang yang terdapat pada Tabel 1. menunjukkan hasil yang berbeda-beda. Berdasarkan hasil tersebut dapat dikatakan bahwa konsentrasi logam berat $\mathrm{Cu}$ pada jaringan lunak $A$. granosa di perairan Tambak Lorok Semarang tidak melebihi baku mutu yang telah ditetapkan berdasarkan SK Depkes RI No.03725/B/SK/1989 untuk biota konsumsi pada logam $\mathrm{Cu}$ yaitu 20 $\mathrm{mg} / \mathrm{kg}$. Pengukuran logam berat $\mathrm{Cu}$ pada Tabel 1 . 
menunjukan bahwa konsentrasi logam berat $\mathrm{Cu}$ tertinggi terdapat pada sampel bulan Juni yaitu 2,209 $\mathrm{mg} / \mathrm{kg}$ dan konsentrasi terendah terdapat pada sampel bulan Maret yaitu $0,705 \mathrm{mg} / \mathrm{kg}$.

Kandungan logam berat $\mathrm{Cu}$ dalam jaringan lunak $A$. granosa diperoleh dari sampel seberat 300 g. Hal tersebut merupakan persyaratan minimal yang diajukan oleh laboratorium Balai Besar Teknologi Pencegahan Pencemaran Industri, Semarang dalam menganalisi logam berat. Analisis logam berat tembaga dilakukan dengan menggunakan alat ICP (Inductively Coupled Plasma) dengan ketentuan sesuai dengan SNI 01-2986-1992.

Analisis kandungan logam berat $\mathrm{Cu}$ pada sampel jaringan lunak A. granosa dilakukan pada bulan Maret, April, Juni dan Juli 2020. Waktu pengambilan sampel tersebut dilakukan berdasarkan musim penangkaran kerang $A$. granosa yang terjadi setelah musim angin barat yaitu saat musim kemarau pada bulan Maret hingga bulan September (Nurdin et al. 2006). Penentuan waktu tersebut juga didasari atas teori Supriyantini dan Soenardjo (2015) bahwa pada musim penghujan konsentrasi logam berat cenderung lebih rendah dan saat musim kemarau logam berat akan terkonsentrasi dan diduga memiliki konsentrasi lebih tinggi. Pengambilan sampel tidak dilakukan pada bulan Mei 2020 disebabkan oleh cuaca yang tidak menentu berdasarkan hasil pantauan oleh Stasiun Klimatologi Semarang pada bulan Mei 2020 curah hujan tergolong tinggi mencapai 83 $\mathrm{mm} / \mathrm{hari}$.

Kandungan logam berat $\mathrm{Cu}$ pada jaringan lunak A. granosa yang didaratkan di TPI Tambak Lorok Semarang yang terdapat pada Tabel 1. menunjukkan bahwa konsentrasi logam berat $\mathrm{Cu}$ pada jaringan lunak $A$. granosa yang didaratkan di TPI Tambak Lorok Semarang tidak melebihi baku mutu yang telah ditetapkan berdasarkan SK Depkes RI No.03725/B/SK/1989 untuk biota konsumsi pada logam $\mathrm{Cu}$ yaitu $20 \mathrm{mg} / \mathrm{kg}$.
Berdasarkan hasil pada Tabel 1 menunjukkan bahwa kandungan logam berat dalam jaringan kerang darah cenderung bervariasi. Tinggi rendahnya konsentrasi yang terkandung dalam kerang darah dapat dipengaruhi oleh musim yang sesuai dengan teori Supriyantini and Soenardjo (2016) yang mengatakan bahwa pada saat musim kemarau logam berat akan terkonsentrasi sehingga kandungannya cenderung lebih tinggi. Pengukuran logam berat $\mathrm{Cu}$ pada Tabel 1 . menunjukan hasil bahwa konsentrasi logam berat $\mathrm{Cu}$ tertinggi sebesar $2,209 \mathrm{mg} / \mathrm{kg}$ terdapat pada sampel bulan Juni yang terjadi saat musim kemarau. Sedangkan konsentrasi terendah terdapat pada sampel bulan Maret yaitu 0,705 $\mathrm{mg} / \mathrm{kg}$. Pengambilan sampel bulan Maret ini dilakukan pada akhir musim penghujan sehingga konsentrasinya cenderung rendah. Penelitian terdahulu oleh Dewi et al. (2017) di Perairan Tambak Lorok Semarang menjelaskan bahwa rata-rata konsentrasi logam berat $\mathrm{Cu}$ dalam kerang darah pada bulan Februari 2017 di awal musim kemarau cenderung lebih tinggi yaitu rata-rata sebesar $1,32 \mathrm{mg} / \mathrm{kg}$ dibandingkan konsentrasi pada musim penghujan di bulan Oktober 2016 dengan rata-rata sebesar $0,923 \mathrm{mg} / \mathrm{kg}$.

Berdasarkan penelitian yang dilakukan Yulianto et al. (2019) mengenai kandungan logam berat $\mathrm{Cu}$ di beberapa wilayah perairan pantai utara di Jawa Tengah menunjukkan bahwa kandungan logam berat $\mathrm{Cu}$ pada kerang A. granosa yang berada di perairan Banjirkanal Barat Kota Semarang berkisar 10,97-14,77 mg/kg. Hasil tersebut apabila dibandingkan dengan hasil pada Tabel 1. menunjukan hasil yang jauh beda. Hal itu diduga karena wilayah pengambilan sampel berada di titik yang berbeda dimana penelitian oleh Yulianto et al. (2019) dilakukan di perairan sungai Banjirkanal Barat. Hal itu sejalan dengan teori Fransisca (2011) bahwa aliran sungai yang mengandung logam berat selanjutnya akan melalui lahan pemukiman, perkotaan dan industri sehingga menerima lebih banyak cemaran logam

Tabel 1. Kandungan Logam Berat Cu dalam Jaringan Lunak Kerang Anadara granosa

\begin{tabular}{ccc}
\hline Bulan & Konsentrasi Logam Berat Cu $(\mathrm{mg} / \mathrm{kg})$ & Standar Baku Mutu \\
\hline Maret & 0,705 & $20 \mathrm{mg} / \mathrm{kg}$ \\
April & 1,628 & \\
Juni & 2,209 & (SK Depkes RI No.03725/B/SK/1989) \\
Juli & 1,149 & \\
\hline Rata-rata & 1,423 & \\
\hline
\end{tabular}


berat dari limbah industri dan rumah tangga melalui drainase perkotaan dan perindustrian, sehingga konsentrasinya cenderung tinggi. Berdasarkan Tabel 1, meskipun kandungan logam berat $\mathrm{Cu}$ yang ditemukan pada jaringan lunak $A$. granosa masih berada di bawah standar baku mutu, namun tetap ditemukan adanya logam berat $\mathrm{Cu}$ dengan rata-rata konsentrasi $1,423 \mathrm{mg} / \mathrm{kg}$. Hal tersebut menjelaskan bahwa perairan Tambak Lorok Semarang telah tercemar logam berat $\mathrm{Cu}$ mengingat adanya bioakumulasi pada kerang $A$. granosa dimana terjadi peningkatan konsentrasi logam berat yang diikut perpindahan dari lingkungan ke organisme (Rahmah et al., 2019). Sumber pencemaran di wilayah ini diduga bersumber dari limbah industri dari pelabuhan Semarang serta limbah domestik yang berasal dari kegiatan masyarakat. Secara spesifik sumber cemaran logam berat $\mathrm{Cu}$ berasal dari pelabuhan dimana logam berat ini banyak dimanfaatkan dalam industri cat sebagai antifouling yang digunakan pada kapal di perairan tersebut.

Analisis logam berat $\mathrm{Cu}$ dilakukan dengan menggunakan sampel biota laut jenis moluska. Organisme ini dapat mengakumulasikan partikel logam berat dalam jaringan tubuhnya sehingga dapat digunakan sebagai bioindikator untuk menilai kualitas lingkungan perairan seperti tingkat cemaran dan perubahan dari cemaran tersebut. Logam berat yang terkandung dalam jaringan lunak kerang ini disebabkan oleh adanya logam berat dan bahan kimia yang masuk ke perairan yang kemudian tersuspensi di dasar perairan sehingga partikel logam berat terserap oleh kerang tersebut. Pemilihan jenis kerang $A$. granosa diduga karena habitatnya di dasar perairan dan cenderung hidup dengan cara membenamkan diri di substrat (Khalil, 2016). Menurut Hutagalung (1991), kandungan logam berat pada sedimen cenderung lebih tinggi yang disebabkan adanya pengendapan karena berat jenis logam berat lebih besar dibandingkan berat jenis air. Hal itu dibuktikan pada penelitian yang dilakukan oleh Dewi et al. (2017) bahwa konsentrasi logam berat $\mathrm{Cu}$ pada sedimen di Perairan Tambak Lorok mencapai 41,225 mg/kg yang tergolong tinggi dan melebihi baku mutu yang ditetapkan oleh NOAA yaitu $38 \mathrm{mg} / \mathrm{kg}$.

Estimasi asupan harian pada Tabel 2. dihitung dengan ketentuan untuk orang dewasa dengan berat badan rata-rata $60 \mathrm{~kg}$ yang mengkonsumsi jaringan lunak $A$. granosa sebanyak 140 g per hari selama kurun waktu 30 tahun (Soegianto et al., 2020). Hasil perhitungan tersebut menunjukkan bahwa asupan harian maksimum logam $\mathrm{Cu}$ yang dapat dikonsumsi oleh manusia dengan rata-rata berat badan $60 \mathrm{~kg}$ berada di kisaran 1,65-5.15 $\mu \mathrm{g} / \mathrm{kg} /$ hari. Berdasarkan data yang disajikan pada Tabel 2. dapat dikatakan bahwa nilai EDI atau estimasi asupan harian untuk logam $\mathrm{Cu}$ oleh manusia tidak melebihi nilai PMTDI (Provisional Maximum Tolerable Daily Intake) atau asupan harian maksimum sementara yang dapat ditoleransi yang disarankan oleh FAO/WHO (2011) yaitu 500 $\mu \mathrm{g} / \mathrm{kg} / \mathrm{hari}$. Meskipun nilai EDI berada jauh di bawah batas toleransi, sebaiknya konsumen yang mengkonsumsi jaringan lunak A. granosa yang diperoleh dari Perairan Tambak Lorok Semarang tetap memperhatikan jumlah jaringan lunak $A$. granosa yang dikonsumsi setiap harinya. Hal tersebut diduga karena konsentrasi logam berat yang terkandung dalam jaringan tubuh kerang dapat berbeda-beda dimana sesuai dengan teori Handayani et al. (2020) yang menyatakan bahwa setiap kerang memiliki kemampuan akumulasi berbeda-beda yang dapat disebabkan oleh beberapa faktor yaitu umur dan ukuran kerang, dimana semakin besar atau semakin tua umur kerang maka semakin baik kemampuannya dalam menyerap partikel yang masuk ke dalam tubuhnya termasuk logam berat.

Perhitungan pada Tabel 3. diperoleh berdasarkan Soegianto et al. (2020) dimana ratarata berat-badan manusia dewasa yaitu $60 \mathrm{~kg}$ yang mengkonsumsi jaringan lunak $A$. granosa sebanyak $140 \mathrm{~g} /$ hari selama 30 tahun dengan frekuensi konsumsi 365 hari/tahun. Berdasarkan hasil perhitungan yang disajikan pada Tabel 3., diketahui bahwa nilai THQ pada semua sampel jaringan lunak $A$. granosa yang diperoleh pada 4 bulan pengambilan sampel di Perairan Tambak Lorok Semarang menunjukkan nilai di bawah 1 . Hal tersebut dapat diartikan konsumsi jaringan lunak $A$. granosa tersebut tidak memberikan dampak non-karsinogen (Tu et al., 2011).

Tabel 2. Estimasi Asupan Harian (EDI) Logam Berat $\mathrm{Cu}$ dalam Kerang A. granosa

\begin{tabular}{ccc}
\hline Bulan & EDI $(\mu \mathrm{g} / \mathrm{kg} / \mathrm{hari})$ & PMTDI \\
\hline Maret & 1.65 & \\
April & 3.80 & $500 \mu \mathrm{g} / \mathrm{kg} / \mathrm{hari}$ \\
Juni & 5.15 & (FAO/WHO, 2011) \\
Juli & 2.68 & \\
\hline
\end{tabular}


Tabel 3. Nilai Target Hazard Quotient (THQ) Logam Berat $\mathrm{Cu}$

\begin{tabular}{ccc}
\hline Bulan & THQ & $\begin{array}{c}\text { Nilai } \\
\text { Rujukan }\end{array}$ \\
\hline Maret & 0.02 & THQ $<1$ \\
April & 0.04 & (Tu et al., \\
Juni & 0.06 & 2011) \\
Juli & 0.03 & \\
\hline
\end{tabular}

Penelitian yang telah dilakukan oleh Sudsandee et al. (2017) mengenai risiko terhadap kesehatan manusia dari mengkonsumsi kerang $A$. granosa di Teluk Thailand dilakukan dengan menghitung nilai THQ dari logam berat $\mathrm{Cu}$ dan logam berat lainnya seperti $\mathrm{Hg}$ dan $\mathrm{Cd}$. Hasil dari penelitian tersebut menjelaskan bahwa nilai THQ masih berada pada batas aman yaitu kurang dari 1 . Meskipun nilai THQ yang didapatkan dari penelitian ini masih berada di bawah batas aman, perlu diketahui bahwa logam berat $\mathrm{Cu}$ sebenarnya tergolong logam berat esensial yang dibutuhkan tubuh dalam berbagai proses metabolisme seperti pembentukkan zat besi yang berguna untuk meningkatkan pertumbuhan dan perkembangan pada anak, perkembangan fungsi otak, meningkatkan kekuatan tulang, dan fungsi imun (Taylor et al., 2020). Namun apabila mengkonsumsi makanan mengandung logam berat $\mathrm{Cu}$ secara berlebihan tentu dapat menyebabkan berbagai masalah kesehatan seperti anemia, immunotoxicity dan kerusakan pada hati dan ginjal (Sudsandee et al., 2017). Hal tersebut telah dijelaskan oleh Ismarti (2016) bahwa efek toksik dari logam berat dapat mengurangi kinerja enzim sehingga metabolisme tubuh dapat terganggu dan dapat menghambat mekanisme tubuh seperti pembentukan hemoglobin dalam darah dan dapat menimbulkan efek toksik dalam tubuh. Mekanisme timbulnya efek toksik tersebut dijelaskan oleh Rahmah et al. (2019) bahwa logam berat yang tersaring ke dalam tubuh kerang akan masuk melalui insang dan terserap melalui proses endosistosis oleh lapisan lipid di dinding sel. Logam berat $\mathrm{Cu}$ yang terkandung dalam sel kemudian akan terikat oleh protein metalitionin yang berfungsi dalam mengurangi efek toksisitas. Logam berat $\mathrm{Cu}$ yang berikatan dengan protein tersebut akan disimpan dalam ginjal, sehingga apabila hal ini terjadi terus menerus dapat terakumulasi dan bersifat toksik.

\section{KESIMPULAN}

Kandungan logam berat tembaga $(\mathrm{Cu})$ pada jaringan lunak $A$. granosa yang diperoleh di Perairan Semarang tidak melebihi ambang batas dengan rata-rata konsentrasi sebesar $1,423 \mathrm{mg} / \mathrm{kg}$. Batas aman maksimum dalam konsumsi logam berat $\mathrm{Cu}$ pada jaringan lunak kerang $A$. granosa untuk orang dewasa berkisar 1,65-5,15 $\mu \mathrm{g} / \mathrm{kg} / \mathrm{hari}$. Penilaian risiko kesehatan dengan menghitung nilai THQ menunjukkan hasil lebih kecil dari satu dengan nilai rata-rata sebesar 0,03 sehingga dapat dikatakan tidak berpotensi memberikan dampak non-karsinogen pada tubuh manusia.

\section{DAFTAR PUSTAKA}

[FAO/WHO] Food and Agricultural Organization of the United Nations/World Health Organization. 2011. Joint FAO/WHO Food Standards Programme Codex Committee Contaminants in Foods. The Hague, The Netherlands.

Badan Pusat Statistik Kota Semarang. 2020. Statistik Daerah Kota Semarang. Badan Pusat Statistik Kota Semarang, $173 \mathrm{hlm}$.

Barik, F., Afiati, N. \& Widyorini, N. 2014. Kajian Kandungan Natrium (Na) dan Logam Berat Timbal $(\mathrm{Pb})$ pada Jaringan Lunak Kerang Darah (Anadara granosa (L.)) dari Perairan Tanjung Emas Semarang dan Perairan Wedung Demak. Journal of Maquares, 3(1):151-159.

Cahyani, M. D., Azizah, R. \& Yulianto, B. 2012. Studi Kandungan Logam Berat Tembaga $(\mathrm{Cu})$ pada Air, Sedimen, dan Kerang Darah (Anadara granosa) di Perairan Sungai Sayung dan Sungai Gonjol, Kecamatan Sayung, Kabupaten Demak. Journal of Marine Research, 1(2):73-79.

Darmono. 1995. Logam dalam Sistem Biologi Makhluk Hidup. Penerbit Universitas Indonesia (UI-Press), Jakarta.

Dewi, M. A., Suprapto, D. \& Rudiyanti, S. 2017. Kadar Logam Berat Tembaga $(\mathrm{Cu})$, Kromium (Cr) Pada Sedimen dan Jaringan Lunak Anadara granosa di Perairan Tambak Lorok Semarang. Journal of Maquares, 6(3):197-204.

Firmansyaf, D., Yulianto, B. \& Sedjati, S. 2013. Studi Kandungan Logam Berat Besi $(\mathrm{Fe})$ dalam Air, Sedimen dan Jaringan Lunak 
Kerang Darah (Anadara granosa Linn) di Sungai Morosari dan Sungai Gonjol Kecamatan Sayung, Kabupaten Demak. Journal of Marine Research, 2(2):45-54.

Fransisca, A. 2011. Tingkat Pencemaran Perairan ditinjau dari Pemanfaatan Ruang di Wilayah Pesisir Kota Cilegon. Jurnal Perencanaan Wilayah dan Kota, 22(2):145-160.

Handayani, P., Kurniawan, K. \& Adibrata, S. 2020. Kandungan Logam Berat Pb Pada Air Laut, Sedimen dan Kerang Darah (Anadara granosa) di Pantai Sampur Kabupaten Bangka Tengah. Jurnal IPTEK Terapan Perikanan dan Kelautan, 1(2):97-105.

Hutagalung, H. P. 1991. Pencemaran Laut oleh Logam Berat dalam Status Pencemaran Laut di Indonesia dan Teknik Pemantauannya. Puslitbang Oceanografi-LIPI, Jakarta.

Ismarti, I. 2016. Pencemaran Logam Berat di Perairan dan Efeknya Pada Kesehatan Manusia. Opini, 1(4):1-11.

Khalil, M. 2016. Bioekologi Kerang Genus Anadara (Bivalvia:Archidae). Sefa Bumi Persada, Aceh.

Nurdin, J., N. Marusin, I. Izmiarti, A. Asmara, R. Deswandi dan J. Marzuki. 2006. Kepadatan Populasi dan Pertumbuhan Kerang Darah Anadara antiquate L. (Bivalvia: Arcidae) di Teluk Sungai Pisang, Kota Padang, Sumatera Barat. Makara Sains, 10(2):96-101.

Rahmah, S., Maharani, H. W. \& Efendi, E. 2019. Konsentransi Logam Berat $\mathrm{Pb}$ dan $\mathrm{Cu}$ Pada Sedimen dan Kerang Darah (Anadara granosa Linn, 1758) di Prairan Pulau Pasaran, Kota Bandar Lampung. Aquatic Sciences Journal, 6(1):22-27.

Selpiani, L., Umroh, U. \& Rosalina, D. 2015. Konsentrasi Logam Berat $(\mathrm{Pb}, \mathrm{Cu})$ Pada Kerang Darah (Anadara granosa) di Kawasan Pantai Keranji Bangka Tengah dan Pantai Teluk Kelabat Bangka Barat. Jurnal Oseotek, 9(1):1-14.

Soegianto, A., Putranto, T.W.C., Lutfi, W., Almiranti, F.N., Hidayat, A. R., Muhammad, A., Firdaus, R.A., Rahmadhani, Y.S., Fadila, D.A.N. \& Hidayati, D. 2020. Concentrations of Metals in Tissues of Cockle Anadara granosa (Linnaeus, 1758) from East Java Coast, Indonesia, and Potential Risks to Human Health. Hindawi International Journal of Food Science, 1-9.

Sudsandee, S., Tantrakarnapa, K., Tharnpoophasiam, P., Limpanont, Y., Mingkhwan, R. \& Worakhunpiset, S. 2017. Evaluating Health Risk Posed by Heavy Metals to Humans Consuming Blood Cockles (Anadara granosa) from the Upper Gulf of Thailand. Environmental Science and Pollution Research, 24(17):14605-14615.

Supriyantini, E. dan Soenardjo, N. 2015. Kandungan Logam Berat Timbal $(\mathrm{Pb})$ dan Tembaga $(\mathrm{Cu})$ Pada Akar dan Buah Mangrove Avicennia marina di Perairan Tanjung Emas Semarang. Jurnal Kelautan Tropis, 18(2):96-108.

Taylor, A.A., Tsuji, J.C., Garry, M.R., McArdle, M.E., Goodfellow Jr, W.L., Adams, W.J. \& Menzie, C.A. 2020. Critical Review of Exposure and Effects: Implications for Setting Regulatory Health Criteria for Ingested Copper. Environmental Management, 65:131-159.

Tu, N.P.C., Ha, N.N., Agusa, T., Ikemoto, T., Tuyen, B.C., Tanabe, S. \& Takeuchi, I. 2011. Trace Elements in Anadara spp. (Mollusca: Bivalvia) Collected along the Coast of Vietnam, with Emphasis on Regional Differences and Human Health Risk Assessment. Fisheries Science, 77:1033-1043.

Widowati, W., Jusuf, R., Sastiono, A. \& Rosari, R. W. 2008. Efek Toksik Logam Pencegahan dan Penanggulangan Pencemaran. Andi, Yogyakarta.

Yulianto, B., Oetari, P.S., Februhardi, S., Putranto, T.W.C. \& Soegianto, A. 2019. Heavy Metals $(\mathrm{Cd}, \mathrm{Pb}, \mathrm{Cu}, \mathrm{Zn})$ Concentrations in Edible Bivalves Harvested from Northern Coast of Central Java, Indonesia. IOP Conf. Series: Earth and Environmental Science, 259:1-10. 